International Journal of Instruction e-ISSN: 1308-1470 • www.e-iji.net

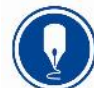

January $2022 \bullet$ Vol.15, No.1

p-ISSN: 1694-609X

pp. 185-196

Article submission code:

20210130101402
Received: 30/01/2021

Revision: 12/06/2021
Accepted: 09/07/2021

OnlineFirst: 17/10/2021

\title{
Accessible Flipped Classroom Model for Pronunciation Instruction: Its Effectiveness and Students' Perception
}

\section{Uswatun Khasanah}

Walailak University, Thailand, uswatun@mail.wu.ac.th

Kiki Juli Anggoro

Walailak University, Thailand, kiki.an@mail.wu.ac.th

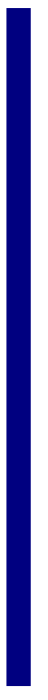
The accessible Flipped classroom is a two-learning phase model that includes pre- class and in-class learning phases accessible using standard information technology. The objectives of this study are to explore the effectiveness and investigate the students' perceptions towards this model to see how the perceptions correlated with the success of the model. This study involved 59 sophomores (98.3\% female and $1.7 \%$ male) between the ages of 20 to 21 from 2 English presentation classes at Walailak University. A pre-test / post-test were conducted to see the effectiveness, while a survey questionnaire of 22 closed-ended questions and 1 open-ended question was given to them at the end of the term of 12 weeks. The questions were classified into four aspects of perceptions: pre-class learning phase, in-class learning phase, word stress pronunciation, and the overall model. The results confirmed the effectiveness of this model as the average students' post- test score (M: 8.38) was notably higher than their pre-test score (M: 7.47). Students' perceptions of each of four aspects were also positively high. However, as bivariate correlations were performed to examine the relationships between the students' perceptions and post-test results, no significant correlation was found. The study implied that even though the students improved by using the model, they might have needed more time to adapt to a more independent learning culture.

Keywords: flipped learning, accessible, technology, ELT, pronunciation

\section{INTRODUCTION}

Pronunciation has been one of the main problems in English learning in Thailand. Thai EFL students simply lack the opportunity to utilize English in their daily lives, causing them to be passive and too shy to use the target language in the classroom (Wiriyachitra, 2002). The condition seems to be worse with insufficient English pronunciation practices at school, which discourages students from speaking English in real life and lessens their confidence in expressing themselves orally due to their pronunciation problems (Kongkerd, 2013). Besides, it is apparent that their mother tongue has highly influenced Thai EFL students' pronunciation. The influence of L1 on students' foreign

Citation: Khasanah, U., \& Anggoro, K. J. (2022). Accessible flipped classroom model for pronunciation instruction: Its effectiveness and students' perception. International Journal of Instruction, 15(1), 185-196. https://doi.org/10.29333/iji.2022.15111a 
language pronunciation has been confirmed (Riney \& Anderson-Hsieh, 1993), and the influence has been visible in Thai EFL students' pronunciation. To tackle this problem, the present study examines the application of flipped classroom model which focuses on pronunciation instruction that emphasizes communication activities, speaker awareness, self-monitoring, and feedback, as suggested by (Anderson-Hsieh,1989). Flipped classroom that utilizes computer technologies can also enhance pronunciation instruction (Gilakjani \& Sabouri, 2016).

The flipped classroom model has recently been among the popular teaching approaches and proven successful in multi-disciplinary fields (Al Mulhim, 2021; Al-Zoubi \& Suleiman, 2021; King, 2020; Phillips \& Trainor, 2014). The flipped model in English teaching and learning is also not a new thing (Sejdiu, 2014; Haghighi et al., 2019; Evseeva \& Solozhenko, 2015). For instance, Evseeva \& Solozhenko (2015) implemented a technological flipped model to English learning providing efficient and accessible tools for studying, and this model increased students' interest in studying English. However, there is still little known about the effectiveness of flipped classroom model for accommodating pronunciation instruction. Therefore, this study attempts to (1) provide empirical evidence regarding the effectiveness of flipped classroom model in improving Thai EFL students' pronunciation and (2) find out how Thai EFL students perceive their learning experiences through flipped classroom model to see whether their perceptions predict their achievement.

\section{Literature Review}

\section{Flipped learning model}

The flipped classroom is usually known for its two phases, including the pre-class learning and the in-class learning phases. In the initial phase, students are required to acquire essential subject knowledge by studying given various types of learning materials, such as audio presentation, online videos, or written materials, before the class (Baker, 2000; Bergmann \& Sams, 2012; Strayer, 2012). In the second phase, students are situated in a student-centered active learning environment in class in which they will experience interactive lectures, problem-solving activities, laboratory practices, act out activities, and group works (Gerstein, 2011; Strayer, 2012). These two phases distinguish flipped classroom from other learning approaches. Many studies have been conducted to confirm the benefits of the flipped learning model in EFL classes (Chen Hsieh et al., 2017; Evseeva \& Solozhenko, 2015; Köroğlu \& Çakır, 2017; Kozikoglu 2019; Zhang et al., 2016).

In the area of pronunciation, a model developed by Zhang et al. (2016) uses microlectures sent to the students three days before the class, and then students learn about the shapes of the mouth and the positions of the tongue in producing the sounds before they go to the class. During the classroom instruction, the teacher can check each students' knowledge and production of the sounds. Then, the teacher gives feedback to address each student's problems. Other practices involve recorded lectures and the teacher's feedbacks. The research proved that in comparison to the traditional method, the flipped learning method helps students reach higher testing scores and confidence. Furthermore, 
this method helps students manage their learning difficulties better. However, though this model has been proven effective in teaching pronunciation, there is still limited literature of research applying this model in pronunciation. A lot of them focus on speaking in general.

Similarly, though many have focused on the students' achievement by using this method and their perception towards it (Haghighi et al., 2019; Abdelshaheed, 2017), there is little empirical evidence about whether the students' perception correlates with or can predict their achievement. The illustration of the model can be seen below. It was noted that Kim et al., (2014) argued that students need to have self-independence in learning to apply flipped classroom model. In addition, students from Southeast Asia, in general, lacked of self-independence (2011).

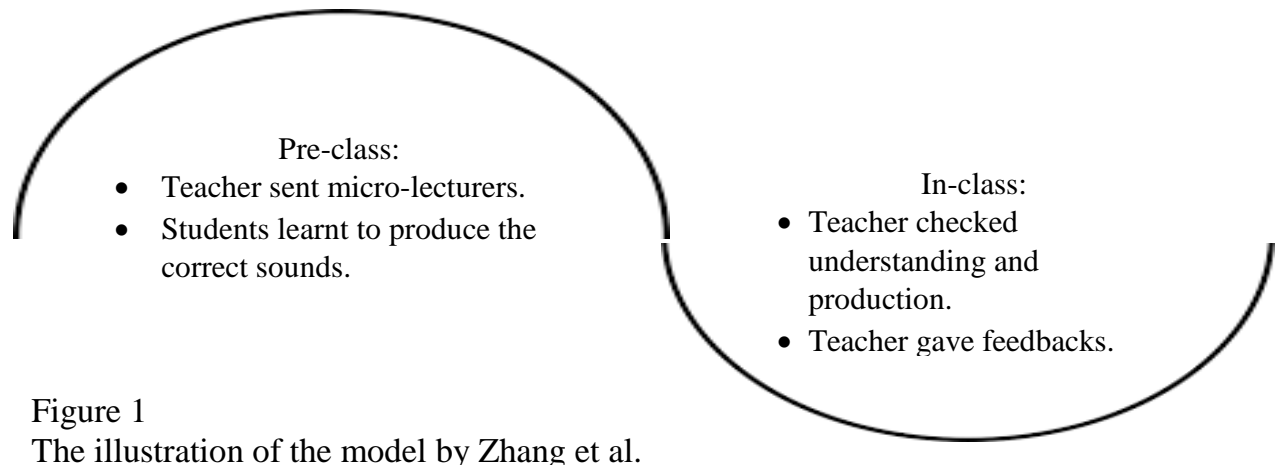

The illustration of the model by Zhang et al.

\section{Accessible flipped classroom model for pronunciation instruction}

Flipped learning can be made accessible using common information technologies widely used by people (Al-Zoubi \& Suleiman, 2021; Quyen and Van Loi, 2018). For instance, Quyen and Van Loi (2018) created a flipped classroom in which the learning materials were accessed through common social media networks such as Facebook. Facebook was used to send documents, post announcements, and give feedback on the students' inquiries. The teaching materials were posted one week before the class to give students some time for preparation. The in-class activities were connected with out-class activities. At the end of the period, students taught with the flipped learning model had better post-test scores.

Furthermore, Fang (2020) proposed a new flipped classroom model for college teaching. The model includes four distinctive stages: teaching planning stage, pre-class learning and guidance stage, class assessment and discussion stage, and after-class learning summary stage. Fang (2020) declared that the new flipped classroom model brought benefits to the experimental group as their performance was noticeably higher than the control counterpart. Therefore, the model is patterned and adapted. Also, the following model takes into account perceived approaches for making a practical flipped course, including to "(1) guarantee students have studied the in-class materials before class; (2) be systematic in instruction; (3) prepare studying materials and activities based on students' suggestion; and, (4) provide applicable immediate support in class" (Long 
et al., 2017). Moreover, to tackle teachers' technological literacy and competency and schools' technological sufficiency challenges (Rasheed et al., 2020), this model deploys common devices such as PC and smartphones as well as easy-to-learn online platforms such as Facebook, Kahoot, Quizizz, and Socrative.

There are four stages in this accessible flipped classroom model to teach pronunciation used in this study.

\section{Preparation}

This stage takes place before the course starts. However, revision is possible to be made during the course. Appropriate changes are possible concerning teachers' and students' reflection. This stage includes four steps, as follows.

- What to Teach

Teachers look at the syllabus to analyze what content should be included in lessons.

- How to Teach

Teachers decide what form of media will best deliver the content in the controlled selfstudy stage and practice and feedback stage.

\section{- Media Making}

Lecture videos and learning materials can be produced and compiled using smartphones, laptops, cameras, and many more. To ensure students' involvement, engaging miniquizzes is necessary. The quizzes should be fun and not stressful. Online quiz platforms such as Kahoot, Quizizz, and Socrative may be the best options.

\section{- Media Sharing}

Facebook is a useful platform to help conduct the flipped model. Facebook is not only chargeless but also the most widely used in Thailand. According to Social Media Stats (2020), Facebook topped the social media stats in Thailand with $61.76 \%$, followed by Twitter, Youtube, Pinterest, Vkontakte, and Instagram. Moreover, time spent with media survey in 2018 by GlobalWebIndex revealed that Thais spend an average of 9 hours and 11 minutes online per person per day. This information is a solid springboard to utilize social media, particularly Facebook, as a flipped classroom platform.

\section{Controlled Self-Study}

As previously mentioned, students are expected to study videos and other materials before attending the class. However, Rasheed et al. (2020) revealed that students' selfregulation skill is a significant challenge in a blended learning environment. Therefore, to ensure their involvement, fun online quizzes play a major role. The students are allowed to take the quiz over and over again before class starts. This will not take away the students' flexibility in controlling their own learning tempo. 


\section{In-Class Practice and Feedback}

The students are to be engaged in collaborative and engaging activities. Peer assessment is an effective way for the students to learn from each other. The pupils are encouraged to exchange partners for expanding their practice time. In class, teachers are expected to have one-on-one or small group counseling to assess and more importantly, give feedback to the students. While waiting for their turn, students are encouraged to video record their language production and post the videos on the FB group. The videos will be a great addition for the teacher to assess and give feedback to the students. Repetitive practice and feedback are expected to affect students' comprehension of how to pronounce the words accurately.

\section{METHOD}

\section{Research Questions}

The study aimed to answer two research questions:

1. Is the new accessible flipped classroom model effective in improving the students' pronunciation?

2. How do students perceive their learning experience with the flipped classroom model, and how do their perceptions correlate with their pronunciation achievement?

\section{Participants}

The participants were 59 sophomore students (98.3\% female and $1.7 \%$ male) between the ages of 20 to 21 from 2 English presentation classes at Walailak University. $41 \%$ percent of them were from medical students and the rest from the school of science. They were chosen randomly as they are speaking-based classes taught by the researchers. The students were in A1 and A2 levels of CEFR. To decide their level, at the beginning of the school year, Walailak University Test of English Proficiency (WUTEP) was conducted. Both groups were given the same treatment to see whether students from both levels of English competence can benefit from this model.

\section{Procedure}

The research was performed during one term consisting of 12 weeks. Three weeks into the term, the first presentation task was conducted (pre-test). In the last week of the term, a post-test was conducted. This time students have upgraded their knowledge, especially in word stress pronunciation, as teachers have given them much feedback throughout times both inside and outside of the classroom.

\section{Illustration of the Flipped Classroom Model}

The term covered 12 weeks of lessons, and the activities were illustrated below. 

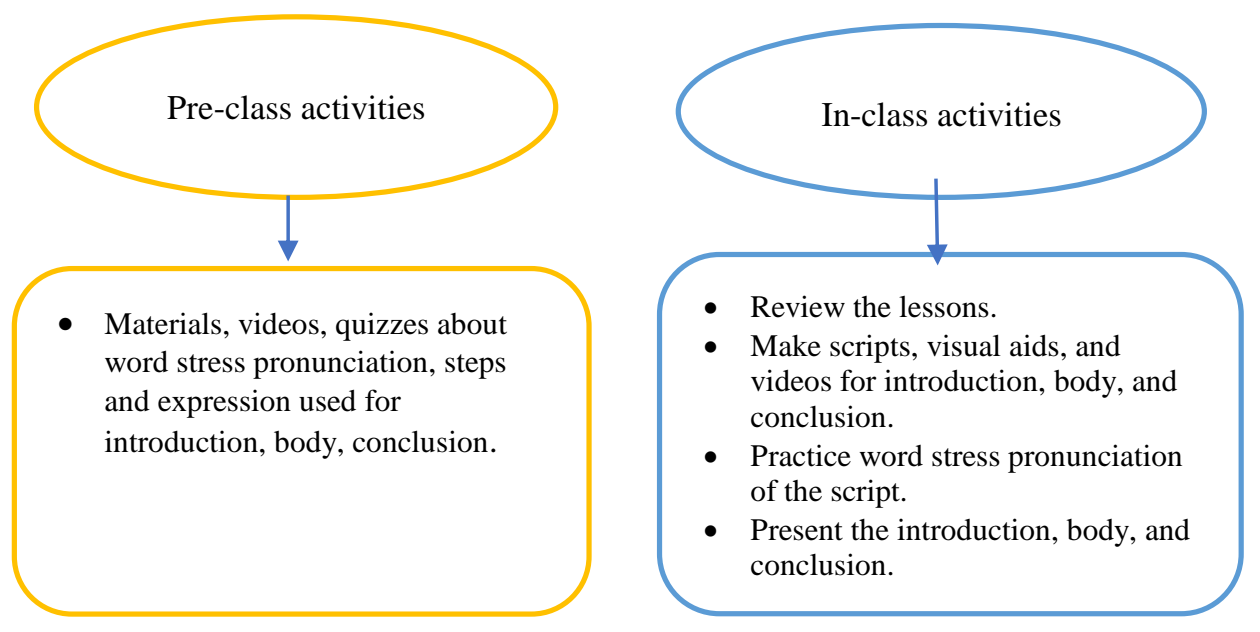

Figure 2

The illustration of the flipped classroom model

\section{Instruments}

The study design involved a quantitative and a qualitative component. The quantitative data were calculated to make reliable results, while the qualitative data were gathered to see the students' emotions, perceptions, and opinions.

\section{Pre and Posttest}

The pre-test and post-test were two similar presentations about the introduction part. The introduction part lasted around 3 to 5 minutes. The pre-test was conducted in week 4 , and the post-test was in week 12 . They were scored based on their introduction to a presentation. Their performance was evaluated using speaking rubrics that covered criteria such as structure, language usage, pronunciation, and delivery. A limitation of this study was the inexistence of the control group.

\section{Survey Questionnaire}

Another instrument, a questionnaire, was given to the students at the end of the term (week 12). The questionnaire included 22 closed-ended questions and 1 open-ended question, and the result was computed to discover the students' perception. The questions were designed with a Likert scale which ranges from 1 (strongly disagree) to 5 (strongly agree) to facilitate students to answer, along with an open-ended question at the end to let students suggest or comment on the lesson. The questionnaire investigated four aspects of this model: the pre-class, in-class, word stress pronunciation practice, and overall model. The reliability of the questionnaire items was evaluated by using Cronbach's Alpha, and the result indicated a very high internal consistency among the items $(\alpha=.992)$. Because of this result, no questionnaire items were deleted. Some samples of the statements in the survey were written below. 
Table 1

Samples of statements students' perception

\begin{tabular}{ll}
\hline Pre-class treatment & I become more responsible for my own learning. \\
\hline In-class treatment & I have more time to consult with the teacher during the lesson. \\
\hline $\begin{array}{l}\text { Word stress pronunciation } \\
\text { treatment }\end{array}$ & $\begin{array}{l}\text { I can identify the word stress of 2-syllable nouns and adjectives, for } \\
\text { example, power, body, and clever. }\end{array}$ \\
\hline The overall model & I understand more about the lesson materials this term. \\
\hline
\end{tabular}

The survey data were analyzed using frequency and descriptive statistics. Three scales were used to interpret the mean, including Low level (1-2.4), Moderate level (2.5 - 3.4), and High level $(3.5-5)$. Also, a qualitative analysis was conducted to see the students' perceptions based on their comments on the open-ended question in the questionnaire. The open-ended question "Write any comments about the class and recommendation for future classes" was analyzed.

\section{FINDINGS}

RQ 1: The Effects of the Accessible Flipped Classroom Model on the Students' Pronunciation.

Table 2

Presentation scores of pre-test and post-test

\begin{tabular}{|c|c|c|c|c|c|}
\hline & & Mean & $\mathrm{N}$ & SD & SE \\
\hline Pair 1 & Pre-test & 7.4746 & 59 & 0.71387 & 0.09294 \\
\hline & Post-test & 8.3858 & 59 & 0.57294 & 0.07459 \\
\hline
\end{tabular}

Table 2 showed an improvement from the average score of pre-test (M:7.47) to post-test (M: 8.38). The paired-sample t-test results of group 1 disclosed that there was a notable difference between students' pre and post-test scores: $\mathrm{t}(23)=-18.650, \mathrm{p}<.001$, with a small effect size (Cohen's d = 1.40)

Table 3

Paired samples test

\begin{tabular}{|c|c|c|c|c|c|c|c|}
\hline & & Mean & SD & SEM & $\mathrm{t}$ & $\mathrm{df}$ & Sig.(2-tailed) \\
\hline Pair 1 & $\begin{array}{l}\text { Pre-test } \\
\text { Post-test }\end{array}$ & -0.91119 & 0.37528 & 0.04886 & -18.65 & 58 & 0 \\
\hline
\end{tabular}

The results from the students' achievement showed that this model can significantly increase the students' achievement. Their pronunciation improved as their presentation scores increased. This model became accessible in improving their scores between the two tests. Moreover, the standard deviation decreased in the second phase from SD = .71 to $\mathrm{SD}=.57$, showing that all students benefitted from this model as the scores were more evenly distributed.

\section{RQ 2: Students' Perceptions and relationships among the variables}

Table 4

Students' perceptions of the four aspects

\begin{tabular}{llcc}
\hline Item & Mean & SD & Level \\
\hline Students' perceptions of the pre-class treatment & 3.94 & .90 & High \\
\hline Students' perception of the in-class treatment & 3.97 & .90 & High \\
\hline Students' perception of word stress pronunciation lesson & 3.84 & .87 & High \\
\hline Students' perception of the whole model & 4.02 & .92 & High \\
\hline
\end{tabular}


When asked about the pre-lesson stage, students needed to rate whether they were comfortable, feel ready, and understand the materials for the class as they learned them before the lesson. The questions also investigated whether they became more active and responsible for learning due to the first stage. The average score for the questions is high (3.94). The questions for the second stage (during the lesson) tried to confirm whether it gave students more time for practice, discussion, feedback, consultation, and supervision. In the end, the questions also wanted the students to confirm whether they understood more and would like to continue to use the flipped learning method in the future. Overall, students gave 3.97 for the second stage. The questionnaire also highlighted the model effectiveness in teaching pronunciation. Factors asked included whether they were aware and understood English two-syllable stress, English words with suffixes and whether the theories and practices help improve their pronunciation. The result showed that the students rated 3,75 on average. When asked if the students understand more by using the flipped learning method and would like to continue to use this model in the future, the average students' rating reached 4.02. The questionnaire involved one open-ended question and mostly responded with positive comments. Some students stated that they liked the class since they had more classroom interactions with teachers and other students. However, a few students mentioned that they would like the home assignments to be reduced. This finding is in line with previous research by Wiriyachitra in 2002, stating that many Thailand students lack the responsibility of their learning. They thought independent learning was homework.

Then, bivariate correlations were performed to examine the relationships between students' perceptions and post-test results. The results indicated positive correlations between the four aspects of students' perceptions on the flipped classroom model: perception of pre- and in- class treatment $(r=.948, p=.000)$, perception of pre-class and pronunciation treatment $(r=.912, p=.000)$, and perception of pre-class treatment and the whole model $(r=.939, p=.000)$. However, no significant correlation was observed between students' perceptions and post-test results: perception of pre-class treatment and post-test $(r=.195, p=.138)$, as seen in Table 5 .

Table 5

The results of Pearson correlations $(\mathrm{N}=59)$

\begin{tabular}{|c|c|c|c|c|}
\hline & $\begin{array}{l}\text { During class } \\
\text { treatment }\end{array}$ & $\begin{array}{l}\text { Word stress } \\
\text { pronunciation treatment }\end{array}$ & Whole model & Post-test \\
\hline Pre-class treatment & $.948^{* *} p=.000$ & $.912 * * p=0.00$ & $.939 * * p=0.00$ & $0.195 p=.138$ \\
\hline In- class treatment & & $.892 * * p=0.00$ & $.976 * * p=0.00$ & $0.256 p=.050$ \\
\hline $\begin{array}{l}\text { Word stress } \\
\text { pronunciation treatment }\end{array}$ & & & $.871^{* *} p=0.00$ & $p=.111$ \\
\hline Whole model & & & & $0.241 p=.066$ \\
\hline Post-test & & & & 1 \\
\hline
\end{tabular}

\section{DISCUSSION}

The effectiveness of the accessible flipped learning model, which was seen through the increase of post-test scores compared to the pre-test scores, was in line with the research by various researchers (Abdelshaheed, 2017; Chen Hsieh et al., 2017; Fang 2020; Haghighi et al., 2019; Köroğlu \& Çakır, 2017; and Van Loi, 2018). Gilakjani \& 
Sabouri, (2016); Köroğlu \& Çakır (2017); and Zhang et al. (2016) mentioned that flipped classroom model was more effective than the traditional model, and this model had helped improve the students' pronunciation as students had more opportunity to have supervised practices during the in-class lesson. Similarly, Chen Hsieh et al. (2017) mentioned that students doing the before class preparation hold a vital role in the success of the flipped model instructions. This accessible model used by students ensures them the work not only by providing easily understood videos but also fun quizzes before the class begins. Besides, teachers' availability before and during the class becomes another main factor in this model's success. Teachers made sure to give timely feedback in and outside the class (Anderson-Hsieh,1989). The perception towards this model was also high as students mentioned they could benefit from the treatment. This finding was congruous with research by Evseeva \& Solozhenko (2015), stating that students became more motivated in learning and by Sejdju (2014) confirming that students accepted the model more positively compared to the traditional model.

Even though the perception is high, it does not correlate significantly to their pronunciation achievement. Each aspect of the students' perception also does not correlate significantly to their achievement. This finding means that students' higher or lower perception does not guarantee higher or lower achievement. This might be the case of self-independence in learning. It is worth noting that for a flipped model to be utilized, students' willingness to study independently needs to be increased (Al Mulhim, 2021 and Kim et al., 2014). While at the same time, independent learning is not something quite familiar in Southeast Asia, including Thailand, as Nguyen (2011) stated that students in Southeast Asia lack self-independence in learning. Thus, even though this model had been proven to increase students' achievement, the students' perception of this model cannot predict their achievement as they still learn to adopt an independent learning culture.

\section{CONCLUSION}

As students did not have many chances to practice their English inside and outside the classroom, their native language, especially in pronunciation, mainly contributes to the production of the English language. Word stress becomes a primary concern because this aspect of pronunciation influences the perception, which can avoid understanding. In Thailand, a lack of interaction in the classroom is one of the driving factors in inhibiting students' pronunciation progress (Kongkerd, 2013). Moreover, he also stated that the common teaching practice has restricted students' right to practice appropriately. Flipped learning as a current method in learning is considered adequate to cover the loopholes traditional models have possessed (Gerstein, 2011; and Strayer, 2012). This model enables more interaction, more controlled practice, and more feedback Gilakjani \& Sabouri, (2016); Köroğlu \& Çakır (2017); and Zhang et al. (2016). These are highly beneficial to improve many aspects of students' pronunciation, including the word stress. Along with the better achievement by using this model, students also gave positive perceptions to this model (Evseeva \& Solozhenko; 2015). 
Thus, this model can be applied anywhere as cases in Thailand also happened in many parts of the world.

However, it was found that their perceptions did not predict their achievement. This finding was a new insight since there was no literature confirming this finding. Lack of students' dependency on learning might have served as a factor as they need to adapt to this new learning method (Nguyen, 2011). Further research is needed to see the correlation between the students' perceptions and achievement. The absence of a control group served as a limitation of this research. The research also included a high number of female students $(98.3 \%)$ in comparison to the male counterparts $(1.7 \%)$. These limitations should be addressed in future studies to get more insights into this model.

\section{REFERENCES}

Al-Zoubi, A. M., \& Suleiman, L. M. (2021). Flipped Classroom Strategy Based on Critical Thinking Skills: Helping Fresh Female Students Acquiring Derivative Concept. International Journal of Instruction, 14(2), 791-810. https://doi.org/10.29333/iji.2021.14244a

Al Mulhim, E. N. (2021). Flipped Learning, Self-Regulated Learning and Learning Retention of Students with Internal/External Locus of Control. International Journal of Instruction, 14(1). https://doi.org/10.29333/iji.2021.14150a

Abdelshaheed, B. S. (2017). Using Flipped Learning Model in Teaching English Language among Female English Majors in Majmaah University. English Language Teaching, $10(11)$, 96-110. https://doi.org/10.5539/elt.v10n11p96

Anderson-Hsieh, J. (1989). Approaches toward teaching pronunciation: A brief history. Cross-Currents, 16(2), 73-78. https://doi.org/10.2307/327275

Al Mulhim, E. N. (2021). Flipped learning, self-regulated learning and learning retention of students with internal/external locus of control. International Journal of Instruction, 14(1), 827-846.

https://doi.org/10.29333/iji.2021.14150a

Baker, J. W. (2000, June 23). The classroom flip: Using web course management tools to become the guide by the side [Paper Presentation]. The11th International Conference on College Teaching and Learning (11th), California, USA. http://classroomflip.com/files/baker_2000_06_23_classroom_flip_CCCU.pdf

Bergmann, J., \& Sams, A. (2012). Flip your classroom: Reach every student in every class every day. International society for technology in education. ASCD.

Chen Hsieh, J. S., Wu, W. C. V., \& Marek, M. W. (2017). Using the flipped classroom to enhance EFL learning. Computer Assisted Language Learning, 30(1-2), 1-21. https://doi.org/10.1080/09588221.2015.1111910 
David. (2019, May 2). Time Spent with Media. Lexicon. https://lexiconthai.com/blog/thailand-leads-the-world-in-time-spent-online/

Evseeva, A., \& Solozhenko, A. (2015). Use of flipped classroom technology in language learning. Proceeding of Social and Behavioral Sciences, 206, 205-209. https://doi.org/10.1016/j.sbspro.2015.10.006

Fang, X. (2020, January). A Study on the New Model of Flipped Classroom Teaching in College English. 2019 International Conference on Education Science and Economic Development (ICESED 2019). Atlantis Press. https://doi.org/10.2991/icesed-19.2020.80

Gerstein, J. (2011, June 13). The flipped classroom model: A full picture. User Generated Education. https://usergeneratededucation.wordpress.com/2011/06/13/theflipped-classroom-model-a-full-picture/

Gilakjani, A. P., \& Sabouri, N. B. (2016). Learners' Listening Comprehension Difficulties in English Language Learning: A Literature Review. English language teaching, $9(6)$ https://doi.org/10.5539/elt.v9n6p123

123-133.

Haghighi, H., Jafarigohar, M., Khoshsima, H., \& Vahdany, F. (2019). Impact of flipped classroom on EFL learners' appropriate use of refusal: achievement, participation, perception. Computer Assisted Language Learning, 32(3), 261-293. https://doi.org/10.1080/09588221.2018.1504083

Kim, M. K., Kim, S. M., Khera, O., \& Getman, J. (2014). The experience of three flipped classrooms in an urban university: an exploration of design principles. The $\begin{array}{llll}\text { Internet Higher } \quad \text { Education, 37-50. } & \text { 22, }\end{array}$ https://doi.org/10.1016/j.iheduc.2014.04.003

King, S. (2020). Formative Assessment Online via Flipped Interactive Screencasts. In P. Wachira \& J. Keengwe (Eds), Handbook of research on online pedagogical models for mathematics teacher education (pp. 257-272). IGI Global. https://doi.org/10.4018/978-1-7998-1476-4.ch016

Kongkerd, W. (2013). Teaching English in the era of English used as a lingua franca in Thailand. Executive Journal, 33(4), 3-12. https://so01.tcithaijo.org/index.php/executivejournal/article/view/80853

Köroğlu, Z. Ç., \& Çakır, A. (2017). Use of Flipped Instruction in Language Classrooms; An Investigation About Student Teachers' Perceptions. European Journal of English Language Teaching, 3(1), 17-39.

http://dx.doi.org/10.46827/ejel.v0i0.993

Kozikoglu, I. (2019). Analysis of the studies concerning flipped learning model: A comparative meta-synthesis study. International Journal of Instruction, 12(1), 851-868. https://doi.org/10.29333/iji.2019.12155a 
Long, T., Cummins, J., \& Waugh, M. (2017). Use of the flipped classroom instructional model in higher education: instructors' perspectives. Journal of computing in higher education, 29(2),

$179-200$. https://doi.org/10.1007/s12528-016-9119-8

Nguyen, C. T. (2011). Challenges of Learning English in Australia towards Students Coming from Selected Southeast Asian Countries: Vietnam, Thailand and Indonesia. $\begin{array}{llll}\text { International } & \text { Education } & \text { Studies, } & 4(1),\end{array}$ https://doi.org/10.5539/ies.v4n1p13

Phillips, C. R., \& Trainor, J. E. (2014). Millennial students and the flipped classroom. Journal of Business and Educational Leadership, 5(1), 102-112. http://asbbs.org/files/ASBBS2014/PDF/P/Phillips_Trainor(P519-530).pdf

Quyen, T. T. T., \& Loi, N. V. (2018). Flipped model for improving students' Englishspeaking performance. Can Tho University Journal of Science, 54(2), 90-97. https://doi.org/10.22144/ctu.jen.2018.012

Rasheed, R. A., Kamsin, A., \& Abdullah, N. A. (2020). Challenges in the online component of blended learning: A systematic review. Computers \& Education, 144, 103701.

https://doi.org/10.1016/j.compedu.2019.103701

Riney, T., \& Anderson-Hsieh, J. (1993). Japanese pronunciation of English. JALT Journal, 15(1), 21-36. https://jalt-publications.org/sites/default/files/pdf-article/jj-15.1art2.pdf

Sejdiu, S. (2014). English language teaching and assessment in blended learning. Journal of Teaching and Learning with Technology, 3(2), 67-82. https://doi.org/10.14434/jotlt.v3n2.5043

Social Media Stats Thailand. (2020). https://gs.statcounter.com/social-mediastats/all/thailand

Strayer, J. F. (2012). How learning in an inverted classroom influences cooperation, innovation and task orientation. Learning Environments Research, 15(2), 171-193. https://doi.org/10.1007/s10984-012-9108-4

Wiriyachitra, A. (2002). English language teaching and learning in Thailand in this decade. Thai TESOL focus, 15(1), 4-9. http://citeseerx.ist.psu.edu/viewdoc/download?doi=10.1.1.475.4155\&rep=rep1\&type=pdf

Zhang, H., Du, X., Yuan, X., \& Zhang, L. (2016). The Effectiveness of the flipped classroom mode on the English pronunciation course. Creative Education, 7(9), 13401346. https://doi.org/10.4236/ce.2016.79139 